\title{
Nota do Corpo Editorial
}

Conforme divulgado no número anterior, e implementando as mudanças decididas na Assembléia Geral, por ocasião do XLI Congresso Brasileiro de Economia e Sociologia Rural, realizado no ano passado em Juiz de Fora, a Revista de Economia \& Sociologia Rural (RER) fez importantes modificações, apresentando ao leitor seu novo projeto editorial. Tal projeto procurou também incorporar as sugestões constantes do Edital do Programa de Apoio às Publicações Científicas do Conselho Nacional de Desenvolvimento Científico e Tecnológico - CNPq.

A capa foi modernizada, apresentando a partir deste número visual moderno e sóbrio. Esta mudança procura refletir e manter a seriedade e qualidade de nossa publicação. O sumário foi modificado para facilitar e melhor apresentar os artigos e seus autores. Visando preservar a memória e dar o devido destaque àqueles que ajudaram a construir e desenvolver nossa Sociedade, atribuímos de forma permanente, na introdução, especial destaque aos Presidentes da SOBER. Adicionalmente, a partir deste número, a RER está normatizada, segundo os parâmetros recentes da Associação Brasileira de Normas Técnicas - ABNT.

Outras mudanças editoriais e em relação ao processo de submissão de artigos, estão sendo estudados pelo Conselho Editorial. 